\title{
IDE DASAR KESEIMBANGAN DALAM PENETAPAN STATUS TERSANGKA SEBAGAI OBJ EK PRAPERADILAN OLEH KEKUASAAN KEHAKIMAN di INDONESIA
}

\author{
Saddam Setia Gultom ${ }^{1}$, RB. Sularto2. \\ Program Studi Magister Ilmu Hukum \\ Fakultas Hukum Universitas Diponegoro
}

\begin{abstract}
Abstrak
Lembaga Kekuasaan Kehakiman yang memberikan perlindungan dan keadilan bagi warga negara, ide dasar keseimbangan di kabulkannya penetapan status tersangka sebagai bagian dari objek praperadilan, bagaimana rekonstruksi pengaturan penetapan status tersangka pasca Putusan Nomor 21/PUU/XII/2014 dalam konteks kekuasaan kehakiman. Penelitian ini dilakukan dengan menggunakan pendekatan yuridis normatif dengan maksud untuk mendapat gambaran dan penjelasan mengenai ide dasar keseimbangan tentang dikabulkannya penetapan status tersangka sebagai objek praperadilan, serta bagaimana rekonstruksi penetapan status tersangka pasca Putusan Mahkamah Konstitusi. Berdasarkan hasil penelitian bahwa ide dasar keseimbangan dalam penetapan status tersangka sebagai objek praperadilan adalah keseimbangan antara masyarakat/individu/tersangka dengan aparat penegak hukum serta keseimbangan antara tersangka dengan masyarakat, tujuannya tidak lain adalah untuk perlindungan hak asasi manusia bagi setiap warga negara. Sehingga pasca putusan tersebut diperlukan adanya perubahan terhadap kitab undang-undang hukum acara pidana yang lebih modern dan memberikan rasa keadilan bagi masyarakat serta perlindungan terhadap hak asasi manusia.
\end{abstract}

\section{Kata Kunci: Ide Dasar Keseimbangan; Kekuasaan Kehakiman; Objek Praperadilan; Penetapan Status Tersangka}

\footnotetext{
${ }^{1}$ Mahasiswa Program Studi Magister IImu Hukum UNDIP

2 Penulis Kedua, Penulis Koresponden
} 


\section{Pendahuluan}

\section{A. Latar Belakang}

Indonesia sebagai negara hukum Peradilan Umum, antara lain: Pengadilan Negeri, sebagaimana tercantum dalam Undang-Undang Pengadilan Agama, Pengadilan Tata Usaha Dasar Negara Repulik Indonesia Tahun 1945 Pasal 1 ayat 3 yang berbunyi negara Indonesia adalah negara hukum artinya adalah Indonesia harus menjungjung tinggi hukum dan kedaulatan hukum, termasuk pengambilan keputusan yang berada di dalam konteks Kekuasaan Kehakiman. Kekuasaan Kehakiman diatur di dalam Bab IX Pasal 24 Undang-Undang Dasar Tahun 1945.

Kekuasaan kehakiman selain diatur di dalam Bab IX Pasal 24 Undang-Undang Dasar Tahun 1945, juga diatur di dalam Undang-undang Negara Republik Indonesia Nomor 48 Tahun 2009 tentang Kekuasaan Kehakiman. Dalam ketentuan umum pada Pasal 1 ayat 1 Undang-Undang Nomor 48 Tahun 2009 tentang kekuasaan kehakiman, dinyatakan bahwa Kekuasaan kehakiman adalah kekuasaan negara yang merdeka untuk menyelenggarakan peradilan guna menegakkan hukum dan keadilan berdasarkan Pancasila dan Undang-Undang Dasar Negara Republik Indonesia Tahun 1945 demi terselenggaranya negara hukum republik Indonesia.

Kekuasaan Kehakiman dilaksanakan oleh sebuah Mahkamah Agung dan badan peradilan yang berada di bawahnya dalam lingkungan Negara, Pengadilan Militer, dan oleh sebuah Mahkamah Konstitusi.

Praperadilan terdiri dari dua kata, yaitu pra dan peradilan. Pra berarti sebelum dan peradilan berarti suatu proses pemeriksaan perkara di depan pengadilan. Secara harafiah berarti sebelum proses pemeriksaan perkara di depan pengadilan. Dengan demikian dapat disimpulkan bahwa Praperadilan adalah suatu proses pemeriksaan voluntair sebelum pemeriksaan terhadap pokok perkara berlangsung di pengadilan.

Praperadilan sebagai salah satu kewenangan pengadilan secara horizontal atau penerapan upaya paksa oleh Polisi dan Jaksa meliputi: (1) sah atau tidaknya penangkapan, penahanan, penghentian penyidikan atau penghentian penuntutan (kecuali terhadap penyampingan perkara untuk kepentingan umum oleh Jaksa Agung); (2) ganti kerugian dan/atau rehabilitasi bagi seorang yang perkara pidananya dihentikan pada tingkat penyidikan atau penuntutan (vide, Pasal 77 KUHAP); (3) sah atau tidaknya benda yang disita sebagai alat pembuktian (vide, Pasal 82 ayat 1 b dan (3) KUHAP); (4) tuntutan ganti kerugian oleh tersangka atau ahli warisnya 
atas penangkapan atau penahanan serta tindakan lain tanpa alasan yang berdasarkan undangundang atau kekeliruan mengenai orang atau hukum yang diterapkan yang perkaranya tidak diajukan ke Pengadilan Negeri (vide, Pasal 95 ayat 2 KUHAP); (5) permintaan rehabilitasi oleh tersangka atas penangkapan atau penahanan tanpa alasan yang berdasarkan undang-undang atau kekeliruan mengenai orang atau hukum yang diterapkan yang perkaranya tidak diajukan ke Pengadilan Negeri ( vide, Pasal 97 ayat 3 KUHAP). 3

Sependapat dengan tulisan Luhut $M$. Pangaribuan, Darwan Prinst dalam bukunya praperadilan dan perkembangannya di dalam praktek menjelaskan pula, bahwa fungsi dan tujuan dari Praperadilan adalah:4 sebagai pengawasan horizontal oleh Hakim Pengadilan Negeri terhadap pelaksanaan tugas penyidik dan penuntut umum, terutama menyangkut upaya paksa. Dengan demikian tujuan Praperadilan adalah untuk menempatkan pelaksanaan hukum pada proporsi yang sebenarnya demi terlindunginya hak azasi manusia, khususnya terjaminnya hak-hak tersangka dan terdakwa dalam pemeriksaan

${ }^{3}$ Luhut M Pangaribuan, Hukum Acara Pidana, Surat Resmi Advokat di Pengadilan, Praperadilan, Eksepsi, pledoi, Duplik, Memori Banding, Kasasi dan Peninjauan Kembali, (Depok: Papas Sinar Sinanti, 20130, hlm. 95.

${ }^{4}$ Darwan Prinst, Op. Cit. hlm. 3. ditingkat penyidikan, penuntutan dan pemeriksaan di depan pengadilan.

Berdasarkan ketentuan Pasal 1 angka 10 Undang-undang Nomor 8 tahun 1981 jo Pasal 77 tentang Kitab Undang-Undang Hukum Acara Pidana (KUHAP); Praperadilan adalah wewenang pengadilan negeri untuk memeriksa dan memutus menurut cara yang diatur dalam undang-undang ini, tentang:

a. Sah atau tidaknya suatu penangkapan dan atau penahanan atas perminataan tersangka atau keluarganya atau pihak lain atas kuasa tersangka;

b. Sah atau tidaknya penghentian penyidikan atau penghentian penuntutan atas permintaan demi tegaknya hukum dan keadilan;

C. Permintaan ganti kerugian atau rehabilitasi oleh tersangka atau keluarganya atau pihak lain atas kuasanya yang perkaranya tidak diajukan ke pengadilan.

Berbicara mengenai ide dasar keseimbangan dalam penetapan status tersangka sebagai objek praperadilan tidak pernah terlepas dari gagasan dasar atau ide dasar atau pokokpokok pikiran sebagai patokan dalam menentukan alasan apa sebenarnya yang membuat para pelaku kekuasaan kehakiman menjadikan penetapan status tersangka sebagai bagian dari objek 
praperadilan. Padahal kita ketahui bahwa penetapan status tersangka dalam peraturan peraundang-undangan kita bukanlah merupakan objek dari praperadilan, artinya tidak terdapat norma baru dalam ketentuan pasal objek praperadilan tersebut. Oleh karena itu Penulis berpendapat bahwa alasan yang mendasar dijadikannya penetapan status tersangka sebagai objek praperadilan yang nantinya akan dijelasakan pada bagian hasil penelitian ini, baik itu karena alasan filosofi atau keadilan, alasan kepastian hukum, kemanusiaan atau alasan tentang hak hak asasi manusia, alasan politik, maupun alasan lainnya.

\section{B. Perumusan Masalah}

Masalah yang diteliti dapat dirumuskan sebagai berikut:

1. Apakah ide dasar keseimbangan di kabulkannya penetapan status tersangka sebagai bagian dari objek praperadilan?

2. Bagaimana rekonstruksi pengaturan penetapan status tersangka di dalam konteks kekuasaan kehakiman?

\section{Tujuan Penelitian}

Tujuan penelitian ini adalah:

1. Untuk mengkaji dan menganalisis tentang ide dasar keseimbangan atas dikabulkannya penetapan status tersangka sebagai bagian dari objek praperadilan.

2. Untuk mengetahui, mengkaji dan menganalisis rekonstruksi pengaturan penetapan status tersangka di dalam bingkai kekuasaan kehakiman.

\section{Metode Penelitian}

Metode yang digunakan dalam penelitian ini adalah metode penelitian yurisdis normatif yaitu penelitian terhadap masalah dengan melihat dari segi peraturan-peraturan yang berlaku. Spesifikasi yang akan digunakan dalam penelitian ini adalah deskriptif analitis, dalam penelitian hukum normatif data yang digunakan adalah data sekunder. Untuk memecahkan isu hukum dan sekaligus memberikan preskripsi mengenai apa yang seogianya, diperlukan sumber-sumber penelitian yang berupa bahan-bahan hukum primer dan bahan-bahan hukum sekunder. ${ }^{5}$

\footnotetext{
5 Peter Mahmud Marjuki, Penelitian Hukum, (Jakarta: Prenada Media Group, 2005), hlm. 141.
} 
Sesuai dengan sumber data yang menggunakan data sekunder dalam penelitian ini, maka metode pengumpulan data dilakukan melalui study kepustakaan (Library study), bahan-bahan yang telah berhasil dikumpulkan dari berbagai sumber, selanjutkan akan disajikan secara selektif dan sistematis, langkah berikutnya data tersebut dibahas/dianalisis dengan metode deskriptif analisis artinya dari semua bahan hukum yang berhasil dikumpulkan dipakai untuk menggambarkan permasalahan sekaligus pemecahan masalahnya yang dilakukan secara kualitatif normatif.

\section{PEMBAHASAN}

\section{A. Ide Dasar Keseimbangan Dikabulkannya Penetapan Status Tersangka Sebagai Bagian dari Objek Praperadilan.}

Pada dasarnya penetapan status tersangka bukan merupakan objek praperadilan sebagaimana yang dimaksud dalam Pasal 77 KUHAP. Pasal 77 KUHAP berbunyi:

Pengadilan negeri berwenang untuk memeriksa dan memutus, sesuai dengan ketentuan yang diatur dalam undang-undang ini tentang: 6

\footnotetext{
${ }^{6}$ Lihat Pasal 77 KUHAP
}

a. Sah atau tidaknya penangkapan, penahanan, penghentian penyidikan atau penghentian penuntutan:

b. Ganti kerugian dan atau rehabilitasi bagi seseorang yang perkara pidananya dihentikan pada tingkat penyidikan atau penuntutan.

Apabila dicermati dalam ketentuan pasal tersebut diatas, bahwa penetapan status tersangka bukan merupakan bagian dari objek praperadilan sebagaimana yang telah diajukan oleh para pelaku tindak pidana korupsi pada masa kini. Yang sangat populer dalam ingatan kita adalah kasus dugaan tindak pidana korupsi yang dilakukan oleh Komisaris Jendral Budi Gunawan yang sangat menghebohkan publik di berbagai penjuru di Indonesia saat ditetapkan oleh Komisi Pemberantasan Tindak Pidana Korupsi sebagai tersangka dalam kasus dugaan tindak pidana korupsi. Namun oleh karena dirinya merasa ditetapkan status sebagai tersangka tidak memenuhi ketentuan Kitab UndangUndang Hukum Acara Pidana, sehingga upaya hukum yang dilakukannya adalah melalui mekanisme upaya hukum Praperadilan. 
Meskipun penetapan status tersangka tidak tercantum dalam ketentuan Pasal 77 KUHAP tersebut diatas, bukan berarti seseorang yang ditetapkan sebagai tersangka tidak dapat mengajukan upaya hukum praperadilan. Perlu untuk diketahui bahwa sistem hukum yang berlaku di Indonesia memang tidak sama seperti sistem hukum Anglo-Saxon yang menganut aliran freie rechtslehre, yang memperbolehkan hakim untuk menciptakan hukum (judge made law). Hal ini sejalan dengan ketentuan Pasal 20 Algemene Bepalingen van Wetgeving voor Indonesie $(A B-A B)$ masih berlaku sepanjang belum dicabut secara tegas oleh UndangUndang berdasarkan Aturan Peralihan UUD 1945 yang menyatakan: "Hakim harus mengadili berdasarkan Undang-Undang". ${ }^{7}$

Hal ini berarti bahwa dalam hukum yang berlaku di Indonesia, Hakim dilarang menafsirkan lebih dari yang seharusnya jika sudah jelas pengaturannya. Namun bukan berarti Hakim menjadi tidak bebas dalam menjalankan kewenangannya. Hakim

\footnotetext{
${ }^{7}$ http://www.hukumonline.com/berita/baca/catatan-atasputusan-praperadilan-komjen-pol-budi-gunawan-broleh-john-ferry-situmeang--sh-. Diunggah pada tangggal 17 Desember 2015.
}

diperkenankan untuk menafsirkan lebih luas suatu peraturan dikala peraturan tersebut tidak jelas maksudnya atau hakim diperkenankan untuk membuat suatu kaidah hukum di saat terjadi kekosongan hukum, karena pada hakekatnya Hakim dilarang menolak perkara dengan alasan tidak ada dasar hukumnya, karena pada dasarnya hukum kita menganut asas penemuan hukum oleh Hakim sebagaimana yang ditentukan dalam UndangUndang Nomor 48 Tahun 2009 tentang Kekuasaan Kehakiman.

Pada ketentuan Pasal 10 ayat (1) ini disebutkan bahwa: 8

"Pengadilan dilarang menolak untuk memeriksa, mengadili, memutus suatu perkara yang diajukan dengan dalih bahwa hukumnya tidak ada atau kurang jelas melainkan wajib untuk memeriksa dan mengadilinya".

Pasal tersebut diatas merupakan arahan dari Pasal 5 ayat (1) yang berbunyi:

"Hakim dan Hakim Konstitusi wajib menggali, mengikuti, dan memahami nilai-nilai hukum dan rasa keadilan yang hidup di dalam masyarakat".

\footnotetext{
${ }^{8}$ Lihat Pasal 10 ayat (1) Undang-Undang Nomor 48 Tahun 2009.
} 
Asas inilah yang sering digunakan oleh para pelaku tindak pidana korupsi dalam mengajukan dalil hukumnya, sehingga tidak ada alasan bagi Pengadilan untuk menolak perkara yang diajukan kepadanya.

Sebelum menjawab pertanyaan tentang ide dasar keseimbangan dikabulkannya penetapan status tersangka sebagai bagian dari objek praperadilan, terlebih dahulu Penulis menyampaikan bahwa sebelumnya penetapan status tersangka sudah dijadikan sebagai objek praperadilan atas dikabulkan perkara Nomor 21/PUU/XII/2014 oleh Mahkamah Konstitusi tentang pengajuan KUHAP. Meskipun belum ditindaklanjuti oleh pemerintah dan juga DPR sesuai amanat Undang-Undang Nomor 12 Tahun 2011 tentang Tata Peraturan PerUndang-Undangan, bukan berarti putusan tersebut tidak dapat dijadikan sebagai sumber hukum atau acuan hukum, karena pada dasarnya Putusan Mahkamah Konstitusi bersifat final dan kekuatan hukum mengikat (final and binding). maksudnya adalah tidak ada upaya hukum lagi, sehingga putusan tersebut sebenarnya sudah dapat dijadikan sebagai sumber hukum karena sifatnya yang mengikat terhadap permasalahan hukum yang ada, khususnya dalam mengajukan upaya hukum praperadilan. Dalam Amar Putusan
Nomor 21/PUU/XII/2014 tentang pengajuan KUHAP tersebut, penetapan status tersangka telah dijadikan sebagai objek praperadilan. Amar Putusan tersebut berbunyi sebagai berikut:

\section{Mengadili:}

Menyatakan

1. Mengabulkan permohonan Pemohon untuk sebagian;

1.1. Frasa "bukti permulaan", "bukti permulaan yang cukup" dan "bukti yang cukup" sebagaimana ditentukan pada Pasal 1 angka 14, Pasal 17 dan Pasal 21 ayat (1) Undang-Undang Nomor 8 Tahun 1981 tentang Hukum Acara Pidana (Lembaran Negara Republik Indonesia 1981, Nomor 76, Tambahan Lembaran Negara Republik Indonesia Nomor 3209) bertentangan dengan Undang-Undang Dasar Negara Republik Indonesia Tahun 1945 sepanjang tidak dimaknai bahwa "bukti permulaan", "bukti permulaan yang cukup"dan "bukti yang cukup" adalah minimal dua alat bukti yang termuat dalam Pasal 184 Undang-Undang Nomor 8 Tahun 1981 tentang Hukum Acara Pidana; 
1.2. Pasal 77 huruf a Undang-Undang Nomor 8 Tahun 1981 tentang Hukum Acara Pidana (Lembaran Negara Republik Indonesia 1981, Nomor 76, Tambahan Lembaran Negara Republik Indonesia Nomor 3209) bertentangan dengan Undang-Undang Dasar Negara Republik Indonesia Tahun 1945 sepanjang tidak dimaknai termasuk penetapan tersangka, penggeledahan dan penyitaan;

1.3. Pasal 77 huruf a Undang-Undang Nomor 8 Tahun 1981 tentang Hukum Acara Pidana (Lembaran Negara Republik Indonesia 1981, Nomor 76, Tambahan Lembaran Negara Republik Indonesia Nomor 3209) tidak mempunyai kekuatan hukum mengikat sepanjang tidak dimaknai termasuk penetapan tersangka, penggeledahan dan penyitaan;

2. Menolak permohonan Pemohon selain dan selebihnya;

3. Memerintahkan pemuatan putusan ini dalam Berita Negara Republik Indonesia sebagaimana mestinya.

Pada amar putusan angkat 1 point 1.2 dan point 1.3 sudah secara jelas dinyatakan bahwa Pasal 77 tersebut bertentangan dengan
Undang-Undang Dasar sepanjang tidak dimaknai termasuk penetapan tersangka serta tidak mempunyai kekuatan hukum mengikat sepanjang tidak dimaknai penetapan tersangka, penggeledahan dan penyitaan. Sebelum upaya Praperadilan Komjen Budi Gunawan, Jerro Waciq, O.C. Kaligis, Dahlan Iskan, Surya Darma Ali, dan para pelaku tindak pidana korupsi lainnya mengajukan penetapan status tersangka sebagai objek praperadilan, Mahkamah Konstitusi telah menjadikan penetapan status tersangka bagian dari Pasal 77 KUHAP, yang artinya putusan tersebut telah dapat dijadikan sumber hukum dalam mengajukan upaya praperadilan. Namun dalam pembahasan kali ini, Penulis akan menjelaskan tentang ide dasar keseimbangan apa yang terdapat dalam putusan atas dikabulkannya penetapan status tersangka sebagai bagian dari objek praperadilan.

Berbicara tentang ide dasar keseimbagan tidak akan pernah terlepas dari gagasan awal, konsep/nilai/asas, pokok-pokok pikiran yang menjadi dasar pemikiran hukum untuk dijadikan sebagai acuan dalam pembaharuan hukum pidana nasional. Pada slide materi kuliah politik hukum Barda 
Nanwawi Arif dijelaskan bahwa9: Dasar pemikiran hukum (ide dasar) pada dasarnya adalah empat nilai dasar, yaitu: nilai keadilan, nilai kepercayaan, nilai kasih sayang dan nilai keseimbangan. Berkaitan dengan empat nilai tersebut diatas, keempat nilai tersebut pada dasarnya telah tercantum di dalam Pancasila sebagai ground norm (Norma Dasar). Landasan ide keseimbangan menurut Barda Nawawi Arif mencakup: Landasan filosofi system hukum nasional yaitu Pancasila, landasan tujuan adalah pembangunan nasional, serta landasan religious yaitu Ketuhanan Yang Maha Esa.

Landasan tersebut di atas, bahwa ide dasar keseimbangan yang terkandung dalam pertimbangan Hakim atas dikabulkannya penetapan status tersangka sebagai objek praperadilan mengacu kepada Pancasila sebagai sumber dari segala sumber hukum. Keseimbangan yang dimaksud disini adalah sebagaimana yang terdapat dalam Sila ke-2 Pancasila, yaitu kemanusiaan yang adil dan beradab serta Sila ke-5 yaitu keadilan social bagi seluruh rakyat Indonesia, artinya hakim dalam mengabulkan penetapan status tersangka sebagai objek praperadilan

9 Barda Nawawi Arif, Slide Materi Kuliah Polituk Hukum. memberikan cerminan tentang nilai keadilan bagi seluruh rakyat Indonesia yang hak-hak asasi-nya dilanggar dan diperlakukan oleh sewenang-wenang oleh aparat penegak hukum, yaitu dengan dikabulkannya penetapan tersangka sebagai objek praperadilan dalam Putusan No.21/PUU/XII/2014, sehingga dengan hal tersebut di atas ide dasar keseimbangan yang terkandung atas dikabulkannya penetapan status tersangka sebagai bagian dari objek praperadilan adalah keseimbangan kepentingan perlindungan masyarakat/individu dengan aparat penegak hukum agar bekerja sesuai dengan ketentuan hukum yang berlaku.

Berikut Pertimbangan hukum oleh Hakim dalam Putusan No.21/PUU/XII/2014 yang cenderung memberikan perlindungan terhadap

masyarakat/individu/tersangka/terdakwa agar aparat penegak hukum memperhatikan aspek hak asasi manusia dalam menetapkan seseorang sebagai tersangka:

1. Bahwa konsep praperadilan berdasarkan Pasal 77 huruf a yang terbatas pada memberikan penilaian terhadap sah atau tidaknya penangkapan, penahanan, penghentian penyidikan dan atau 
penghentian penuntutan, jelas sepenuhnya tidak dapat memberikan perlindungan yang cukup kepada seorang tersangka dari pelanggaran terhadap hak asasi manusia yang dilakukan oleh penyidik, penuntut umum dan hakim;

2. Bahwa konsep praperadilan berdasarkan Pasal 77 huruf a yang terbatas pada memberikan penilaian terhadap sah atau tidaknya penangkapan, penahanan, penghentian penyidikan dan atau penghentian penuntutan, jelas sepenuhnya tidak dapat memberikan perlindungan yang cukup kepada seorang tersangka sehingga menimbulkan pelanggaran terhadap hak asasi manusia, oleh karenanya bertentangan dengan Pasal 1 ayat (3), Pasal 28D ayat (1), dan Pasal 28I ayat (5) Undang-Undang Dasar Negara Republik Indonesia Tahun 1945;

Demikian juga tentang Pendapat Mahkamah Konstitusi dalam pertimbangannya pada No.3.14 poin 2 dan No. 3.16 adalah sebagai berikut:

1. Bahwa asas duo procces of law sebagai perwujutan pengakuan hak- hak asasi manusia dalam proses peradilan pidana menjadi asas yang harus dijunjung tinggi oleh semua pihak, terutama bagi para lembagalembaga penegak hukum. Perwujutan penghargaan hak asasi tersebut terlaksana dengan memberikan posisi yang sama termasuk dalam proses peradilan pidana, khususnya bagi tersangka, terdakwa maupun terpidana untuk mempertahankan hak-haknya secara seimbang;

2. Bahwa Pasal 77 huruh a KUHAP bertentangan dengan Pasal 1 ayat 3 dan Pasal 28I ayat (5) UUD 1945 apabila tidak dimaknai mencakup sah tidaknya penetapan tersangka, penggeledahan, penyitaan, dan pemeriksaan surat; Mahkamah berpendapat:

a) Bahwa Pasal 1 ayat (3) UUD 1945 menegaskan Indonesia adalah negara hukum. Dalam negara hukum asas duo procces of law sebagai salah satu perwujutan pengakuan hak asasi manusia dalam proses peradilan pidana menjadi asas yang harus dijunjung tinggi oleh semua pihak terutama lembaga penegak hukum. 
Perwujutan penghargaan hak asasi tersebut terlaksana dengan memberikan posisi yang seimbang berdasarkan kaidah hukum yang berlaku, termasuk proses peradilan pidana, khusunya bagi tersangka, terdakwa maupun terpidana untuk mempertahankan hak-haknya secara seimbang. Oleh karena itu, negara khususnya Pemerintah berkewajiban untuk memberikan perlindungan, pemajuan, penegakan dan pemenuhan terhadap HAM (vide Pasal 28I ayat (4) UUD 1945);

b) Penegakan hukum harus sesuai dengan ketentuan yang berlaku juga berdasarkan Pancasila dan UndangUndang Dasar Tahun 1945. Hukum tersebut harus ditegakkan demi terciptanya tujuan dan cita-cita bangsa Indonesia sebagaimana yang dirumuskan pada Pembukaan UUD 1945 alinia ke- empat yaitu, membentuk suatu Pemerintahan Negara Indonesia yang melindungi segenap bangsa Indonesia dan seluruh tumpah darah Indonesia dan untuk memajukan kesejahteraan umum, mencerdaskan kehidupan bangsa, dan ikut melaksanakan ketertiban dunia yang berdasarkan kemerdekaan, perdamain abadi dan keadilan social. Rakyat Indonesia harus aman dari berbagai ancaman bahaya yang datang, rasa aman yang diberikan negara tidak hanya kepada mereka yang benar saja, akan tetapi bagi mereka yang melakukan kesalahan ataupun bagi mereka yang diduga melakukan kesalahan juga berhak memperoleh jaminan rasa aman terhadap diri mereka.

Dari pertimbangan hukum serta pendapat Mahkamah tersebut bahwa Ide keseimbangan yang tercantum atas dikabulkannya penetapan status tersangka sebagai objek praperadilan menurut Penulis adalah keseimbangan dua kepentingan hukum yaitu keseimbangan antara masyarakat/individu/tersangka dan aparat penegak hukum agar berjalan sesuai dengan prosedur ketentuan hukum serta sesuai dengan amanat Pancasila dan UUD Tahun 1945 10Tujuannya adalah untuk menciptakan suatu proses penegakan hukum yang didasarkan pada kerangka due procces of law. Due process of law pada dasarnya bukan semata-

\footnotetext{
10 Putusan Pengadilan Negeri Jakarta Selatan
} Nomor.04.Pid/Pra/PN. Jaksel. 
mata mengenai rule of law, akan tetapi merupakan unsur yang esensial dalam penyelenggaraan peradilan yang intinya adalah bahwa ia merupakan "a law which hears before if condemns, which proceeds upon inquiry, and renders judgement only after trial", dengan kata lain hukum yang mendengar sebelum mengutuk, berlangsung proses penyelidikan, dan membuat penilain setelah sidang, hal ini merupakan makna dari asas praduga tidak bersalah (presumption of innocent).

Ketentuan Perlindungan Hak Asasi Manusia dalam Undang-Undang Dasar Negara Republik Indonesia Tahun 1945:

Pasal 28 D ayat (1) Undang-Undang Dasar Negara RI 1945 berbunyi:

"Setiap orang berhak atas pengakuan, jaminan, perlindungan dan kepastian hukum yang adil serta perlakuan yang sama dihadapan hukum".

Pasal 28I ayat (4)

"Perlindungan, pemajuan, penegakan, dan pemenuhan hak asasi manusia adalah tanggung jawab negara, terutama pemerintah".

Sehingga dengan demikian, secara jelas dan tegas Undang Undang Dasar Negara Republik Indonesia Tahun 1945 telah mengatur perlindungan dan kepastian hukum yang adil bagi setiap warga negara. Terlebih lagi Negara Republik Indonesia telah meratifikasi International Covenant On Civil and Political Right/Konvenan Internasional Tentang hak-hak Sipil dan Politik (ICCPR), yakni melalui Undang-Undang Nomor 12 Tahun 2005 Tentang pengesahan International Covenant On Civil and Political Right (Konvenan Internasional Tentang hakhak Sipil dan Politik), ("UU KONVENAN INTERNASIONAL").

Kewajiban negara untuk melindungi dan menjamin HAM ini secara tegas dicantumkan dalam Pasal 2 ayat (1) ICCPR yang menyatakan: ${ }^{11}$

"Each state party to the present Covenant undertakes to respects and to ensure to all individuals within its territory and subject to its jurisdiction the right recognized in the present covenant".

terjemahan

"Setiap negara pihak pada Kovenan ini berjanji untuk menghormati dan menjamin untuk semua individu dalam wilayahnya dan tunduk pada wilayah

\footnotetext{
${ }^{11}$ Pasal 2 ayat (1) ICCPR
} 
hak hukumnya yang diakui dalam kovenan in".

\section{B. Rekonstruksi Pengaturan Penetapan Status Tersangka di Dalam Konteks Kekuasaan Kehakiman.}

Selama ini, defenisi atau pengertian tentang rekonstruksi masih jarang ditemukan dalam buku-buku hukum atau di berbagai literature yang lain. Meskipun kata rekonstruksi sering kita dengar dalam bahasa kepolisian tentang rekonstruksi tindak pidana, namun pengertian tentang rekonstruksi di dalam Undang-Undang tentang Kepolisian Negara Republik Indonesia tidak di terangkan secara nyata dan jelas tentang pengertian atau istilah rekonstruksi tersebut. Secara harfiah kata rekonstruksi dalam bahasa Inggris berasal dari kata reconstruct. Reconstruct mendapat akhiran ion menjadi reconstruction yang merupakan sebuah kata benda yang berarti membangun atau pembangunan kembali. Dalam terminology hukum rekonstruksi sering disebut reka ulang atau reconstruction the crime.

Rekonstruksi juga dapat diartikan sebagai upaya pembaharuan hukum positif, dalam arti bahwa rekonstruksi pada pokok pembahasan ini adalah pembaharuan hukum acara pidana (criminal procedure code renewel), dengan kata lain pembaharuan tentang peraturan Perundang-Undangan Hukum Acara Pidana Nasional tentang pengaturan penetapan status tersangka dalam peraturan Perundang-Undangan. Rekonstruksi mencakup tentang rekonstruksi substansi hukum nasional dan rekonstruksi pemikiran/konseptual hukum acara pidana nasional.

Berbicara tentang rekonstruksi atau pembaharuan hukum nasional tentunya tidak terlepas dari politik hukum (legal policy) dalam kaitannya dengan pembaharuan hukum acara pidana nasional. Penulis membaca dari berbagai literature pada umumnya bahwa politik hukum adalah kebijakan yang dilakukan oleh pemerintah untuk mencapai tujuan negara. Dalam sebuah buku tentang politik hukum di Indonesia, bahwa menurut Mahfud MD politik hukum adalah ${ }^{12}$

"Legal policy atau garis kebijakan resmi tentang hukum yang akan diberlakukan baik dengan perbuatan hukum baru maupun dengan penggantian hukum yang lama, dalam rangka mencapai tujuan negara"

${ }^{12}$ Mahfud, MD, Politik Hukum di Indonesia, (Jakarta: Rajawali Pers, 2011) hlm. 1. 
Dengan demikian, politik hukum merupakan pilihan tentang hukum-hukum yang akan diberlakukan sekaligus pilihan tentang hukum-hukum yang akan dicabut atau tidak diberlakukan yang kesemuanya dimaksudkan untuk mencapai tujuan negara seperti yang tercantum dalam Pembukaan UUD 1945.

Menurut pakar lain, seperti yang dikemukan oleh Padmo Wahjono bahwa politik hukum adalah kebijakan dasar yang menentukan arah, bentuk, maupun isi hukum yang akan dibentuk. ${ }^{13}$ Sementara Teuku Mohamad Radhie mendefenisikan politik hukum sebagai suatu pernyataan kehendak penguasa negara mengenai hukum yang berlaku di wilayahnya dan mengenai arah perkembangan hukum yang akan dibangun. ${ }^{14}$

Politik hukum juga pernah dikemukakan oleh Sudarto, bahwa menurut beliau "politik hukum" adalah:15

a. Usaha untuk mewujudkan peraturanperaturan yang baik sesuai dengan keadaan dan situasi pada suatu saat;

b. Kebijakan dari negara melalui badanbadan yang berwenang untuk

\footnotetext{
${ }^{13}$ Wahjono, Padmo, dalam Mahfud MD, Ibid, hlm. 1.

14 Ibid

15 Sudarto dalam Barda Nawawi Arif, Bunga Rampai Kebijakan Hukum Pidana, (Jakarta: Kencana, 2011) hlm. 26.
}

menetapkan peraturan peraturan yang dikehendaki yang diperkirakan bias digunakan untuk mengekpresikan apa yang terkandung dalam masyarakat dan untuk mencapai apa yang dicitacitakan.

Untuk mencapai pembaharuan hukum nasional sangat dibutuhkan kemauan politik (political will) dari Pemerintah dan Dewan Perwakilan Rakyat melalui sarana politik hukum, sehingga pembaharuan hukum nasional dapat berjalan dengan lancar. Rekonstruksi atas Putusan Mahkamah Konstitusi tentang pengaturan penetapan status tersangka sebagai objek praperadilan dalam konteks kekuasaan kehakiman sebenarnya sudah diatur dalam UndangUndang Nomor 12 Tahun 2011 tentang Pembentukan Tata Peraturan PerundangUndang.

Dalam Undang-Undang Republik Indonesia Nomor 12 Tahun 2011 tentang Pembentukan Peraturan Perundang-Undang telah ditentukan dalam Pasal 10 bahwa:

1. Materi muatan yang harus diatur dalam Undang-Undang ini berisi:

a. Pengaturan lebih lanjut mengenai ketentuan Undang-Undang Dasar 
Dasar Negara Republik Indonesia Tahun 1945;

b. Perintah suatu Undang-Undang untuk diatur dengan UndangUndang;

c. Pengesahan perjanjian internasional tertentu;

d. Tindak lanjut atas putusan Mahkamah Konstitusi;

e. Pemenuhan kebutuhan hukum dalam masyarakat.

2. Tindak lanjut atas Putusan Mahkamah Konstitusi sebagaimana pada ayat (1) huruf d dilakukan oleh DPR dan Presiden.

Pada Pasal 10 ayat (2) disebutkan bahwa Putusan Mahkamah Konstitusi harus ditindak lanjuti oleh DPR dan juga Presiden sebagaimana lanjutan dari Pasal 10 ayat (1) huruf d. Dalam Penjelasan Pasal 10 (1) huruf d, yang dimaksud "tindak lanjut Putusan Mahkamah Konstitusi" terkait dengan putusan Mahkamah Konstitusi mengenai pengujian Undang-Undang terhadap Undang-Undang Dasar Negara Republik Indonesia Tahun 1945. Materi muatan yang dibuat terkait dengan ayat, pasal, dan/atau bagian Undang-Undang yang secara tegas dinyatakan dalam Putusan Mahkamah Konstitusi bertentangan dengan
Undang-Undang Dasar Negara Republik Indonesia Tahun 1945.

Pada penjelasan ayat (2) disebutkan bahwa:

"Tindak Lanjut atas putusan Mahkamah Konstitusi dimaksudkan untuk mencegah terjadinya kekosongan hukum"

Pada dasarnya objek Praperadilan telah diatur di dalam Undang-Undang Nomor 8 Tahun 1981 tentang Kitab Undang-Undang Hukum Acara Pidana, tepatnya pada bagian kesatu Pasal 77 Kitab Undang-Undang Hukum Acara Pidana.

Pasal 77 berbunyi:

Pengadilan Negeri berwenang untuk memeriksa dan memutus, sesuai dengan ketentuan yang diatur dalam Undang-Undang ini tentang:

a. Sah atau tidaknya penangkapan, penahanan, penghentian penyidikan atau penghentian penuntutan;

b. Ganti kerugian dan atau rehabilitasi bagi seorang yang perkara pidananya dihentikan pada tingkat penyidikan atau penuntutan.

Dilihat dari ketentuan Pasal tersebut diatas, bahwa penetapan status tersangka bukanlah merupakan objek praperadilan, namun setelah adanya Putusan Mahkamah 
Konstitusi Nomor 21/PUU-XII/2014 tentang pengajuan KUHAP termasuk Pasal 77 KUHAP, bahwa penetapan status tersangka merupakan objek praperadilan. Hal tersebut sebagaimana terdapat dalam Amar Putusan Nomor 21/PUUXII/2014 yang berbunyi:

Menyatakan:

- Pasal 77 huruf a Undang-Undang Nomor 8 Tahun 1981 tentang Hukum Acara Pidana (Lembaran Negara Republik Indonesia 1981, Nomor 76, Tambahan Lembaran Negara Republik Indonesia Nomor 3209) bertentangan dengan Undang-Undang Dasar Negara Republik Indonesia Tahun 1945 sepanjang tidak dimaknai termasuk penetapan tersangka, penggeledahan dan penyitaan;

- Pasal 77 huruf a Undang-Undang Nomor 8 Tahun 1981 tentang Hukum Acara Pidana (Lembaran Negara Republik Indonesia 1981, Nomor 76, Tambahan Lembaran Negara Republik Indonesia Nomor 3209) tidak mempunyai kekuatan hukum mengikat sepanjang tidak dimaknai termasuk penetapan tersangka, penggeledahan dan penyitaan;

Artinya sepanjang tidak dimaknai tentang penetapan status tersangka, penggeledahan serta penyitaan, Pasal 77
KUHAP tersebut bertentangan dengan Undang-Undang Dasar Negara Republik Indonesia Tahun 1945. Namun dalam perkembangannya sampai saat ini Putusan Mahkamah Konstitusi tersebut belum ditindak lanjuti oleh Pemerintah dan DPR sesuai amanat Undang-Undang Nomor 12 Tahun 2011 tentang Pembentukan Peraturan Perundang-Undangan. Oleh karena itu masih terjadi kekosongan hukum terhadap Pasal 77 KUHAP, dimana penetapan status tersangka tidak serta merta masuk dalam ranah objek praperadilan, hal ini terbukti ketika banyaknya permohonan yang di tolak oleh Pengadilan atas pengajuan penetapan status tersangka sebagai objek praperadilan.

Untuk mengisi kekosongan hukum tersebut sudah sepatutnya Pemerintah dan DPR melakukan rekonstruksi/pembaharuan terhadap Kitab Undang-Undang Hukum Acara Pidana yang berlaku saat ini untuk mencapai keadilan masyarakat serta memenuhi kebutuhan hukum masyarakat modern saat ini

Rekonstruksi yang dimaksud adalah pembaharuan hukum terhadap UndangUndang Nomor 8 Tahun 1981 tentang Kitab Undang-Undang Hukum Acara Pidana baik itu melalui perubahan terhadap Pasal 77 KUHAP sehingga tidak terjadi kefakuman atau 
kekosongan hukum yang menimbulkan perdebatan di masyarakat luas dan ahli hukum.

\section{PENUTUP}

\section{A. Kesimpulan}

Setelah melakukan rangkaian pembahasan dari Bab I sampai dengan Bab III, maka Penulis mengambil suatu kesimpulan sebagai berikut:

1. Pada dasarnya penetapan status tersangka bukan merupakan objek sengketa praperadilan, dimana dalam ketentuan Pasal 77 Undang-Undang Nomor 8 Tahun 1981 tentang Kitab Undang-Undang Hukum Acara Pidana menyebutkan bahwa praperadilan hanya berwenang untuk memutus sesuai dengan undang-undang tentang, sah atau tidaknya penangkapan, penahanan, penghentian penyidikan, atau penghentian penuntutan, serta ganti kerugian dan atau rehabilitasi bagi seorang yang perkara pidananya dihentikan pada tingkat penyidikan atau penuntutan. Namun pasca Putusan Mahkamah Konstitusi Nomor 21/PUU/XII/2014 tentang Pengujian Kitab Undang-Undang Hukum Acara Pidana khusunya Pasal 77 KUHAP, Hakim Mahkamah Konstitusi menyatakan dalam
Amar Putusannya yang pada intinya adalah bahwa Pasal 77 Kitab Undang-Undang Hukum Acara Pidana bertentangan dan tidak mempunyai kekuatan mengikat sepanjang tidak dimaknai termasuk penetapan status tersangka, penggeledahan dan penyitaan. Sehingga dalam pandangan hukum dari Putusan tersebut penetapan tersangka merupakan bagian dari objek Praperadilan. Dari paparan hal tersebut diatas, menurut Penulis Ide dasar keseimbangan tentang dikabulkannya penetapan status tersangka sebagai objek praperadilan dilihat dari pertimbangan hakim adalah keseimbangan antara masyarakat/individu (termasuk tersangka/terdakwa) dengan aparat penegak hukum. Tujuannya adalah untuk menjaga hak asasi manusia, hak tersangka supaya tidak diperlakukan secara sewenang-wenang oleh Aparat Penegak Hukum (APL). Dengan demikian Aparat Penegak Hukum (APL) dalam melakukan tugasnya sebagai penegak hukum dapat melaksanakan tugasnya sesuai dengan ketentuan Peraturan Perundang-undangan yang berlaku. Hal ini merupakan perwujudan nilai-nilai Pancasila dan Undang-Undang Dasar Negara Republik 
Indonesia Tahun 1945 yang menjadilan hukum sebagai panglima tertinggi untuk memberikan keadilan bagi setiap warga negara.

2. Rekonstruksi selain dapat diartikan sebagai reka ulang, membentuk kembali, rekonstruksi juga dapat diartikan sebagai pembaharuan hukum nasional yang menyangkut substansi hukum. Rekonstruksi pengaturan penetapan status tersangka di dalam konteks kekuasaan kehakiman adalah menyangkut pembaharuan hukum positif, rekonstruksi pada pokok pembahasan ini menyangkut tentang pembaharuan hukum acara pidana (criminal procedure code). Dengan kata lain adalah pembaharuan peraturan perundang-undangan tentang Kitab Undang-Undang Hukum Acara Pidana Nasional di masa mendatang yang menyangkut tentang pengaturan kembali penetapan status tersangka sebagai objek praperadilan. Tujuan dari rekonstruksi penetapan status tersangka sebagai objek praperadilan Pasca Putusan Mahkamah Konstitusi Nomor 21/PUU/XII/2014 serta Putusan Nomor 04/Pid/Pra/PN. Jakarta selatan ini adalah untuk menjaga agar tidak terjadi kekosongan hukum dan penafsiran yang beragam terhadap Pasal 77 UndangUndang Nomor 8 Tahun 1981 tentang Kitab Undang-Undang Hukum Acara Pidana. Dengan adanya rekonstruksi terhadap Pasal 77 KUHAP sehingga objek Praperadilan tersebut bertambah yang pada awalnya terbatas pada sah atau tidaknya penangkapan, penahanan, penghentian penyidikan, atau penghentian penuntutan, serta ganti kerugian dan atau rehabilitasi bagi seorang yang perkara pidananya dihentikan pada tingkat penyidikan atau penuntutan, menjadi terdapat penambahan yaitu penetapan tersangka, penggeledahan dan penyitaan. Hal tersebut juga sebagai amanat Pasal 10 ayat (1) dan ayat (2) Undang-Undang Republik Indonesia Nomor 12 Tahun 2011 tentang Pembentukan Peraturan Perundang-Undang yang menyebutkan bahwa Putusan Mahkamah Konstitusi harus ditindaklanjuti oleh Presiden dengan Dewan Perwakilan Rakyat Republik Indonesia, tujuannya adalah sebagaimana dalam penjelasan Pasal 10 ayat (2) yaitu untuk mencegah terjadinya kekosongan hukum. 


\section{B. Saran}

Dengan dikabulkannya Putusan Nomor 21/PUU/XII/2014 tentang pengujian terhadap Kitab Undang-Undang Hukum Acara Pidana khusunya yang berkaitan dengan Pasal 77 tentang objek praperadilan serta Putusan Nomor 04/Pid/Pra/PN. Jaksel tentang praperadilan, untuk menjaga keseimbangan kepentingan masyarakat/individu/tersangka dengan aparat penegak hukum supaya penegak hukum bekerja dalam ketentuan yang sah tanpa sewenang-wenang, sepatutnya Putusan Mahkamah Konstitusi dan Putusan Pengadilan Negeri Jakarta Selatan yang mengabulkan penetapan status tersangka sebagai objek praperadilan dibahas dan disahkan oleh Presiden dengan Dewan Perwakilan Rakyat dengan ketentuan melakukan perubahan terhadap UndangUndang Nomor 8 Tahun 1981 tentang Kitab Undang-undang Hukum Acara Pidana khusunya yang berkaitan dengan objek praperadilan.

\section{DAFTAR PUSTAKA}

\section{A. Buku-buku:}

Prinst, Darwan, Praperadilan dan Perkembangannya di dalam Praktek, (Bandung: PT. Citra Aditya Bakti, 1993).
Andi Hamzah, Jur, Hukum Acara Pidana Indonesia, (Jakarta: Sinar Grafika, 2011).

Tanusubroto, S, Peranan Praperadilan Dalam Hukum Acara Pidana, (Bandung: Alumni, 1983).

Pangaribuan, Luhut.MP, Hukum Acara Pidana; Surat Resmi Advokat di Pengadilan (Praperadilan, Eksepsi, Pledoi, Duplik, Memori Banding, Kasasi dan Peninjauan Kembali, (Depok Timur: Papas Sinar Sinanti, 2013).

Bambang Sutiyoso dan Sri Hastuti Puspitasari, Aspek-Aspek Perkembangan Kekuasaan Kehakiman Di Indonesia, (Yogyakarta: UII Press Yogyakarta, 2005).

Rahayu, Hukum Hak Asasi Manusia (HAM), (Semarang:Universitas Diponegoro, 2010).

Mahfud, MD, Politik Hukum di Indonesia, (Jakarta: Rajawali Pers, 2011)

Barda Nawawi Arif, Bunga Rampai Kebijakan Hukum Pidana, (Jakarta: Kencana, 2011).

Barda Nawawi Arif, Perbandingan Hukum Pidana (Jakarta: PT. Raja Grafindo Persada, 2011). Rimdan, Kekuasaan Kehakiman Pasca Amandemen, (Jakarta: Kencana, 2012)

M. Tahir Azhari, Negara Hukum Suatu Studi tentang Prinsip-Prinsipnya Dilihat dari Segi Hukum Islam, Implementasinya pada 
Periode Negara Madinah dan Masa Kini, Undang-undang Nomor 49 tahun 2009 tentang (Jakarta: Bulan Bintang, 1992). perubahan kedua atas Undang-undang K.Wantjik Saleh, Kehakiman dan Peradilan, Nomor 2 tahun 1986 tentang Peradilan (Jakarta: Simbur Cahaya, 1976). Umum.

Saidi, Muhammad Djafar, Perlindungan Hukum

\section{J urnal Hukum:}

Wajib Pajak dalam Penyelesaian Sengketa

Hamid S. Attamini, Peranan Keputusan Presiden RI

Pajak, (Jakarta : PT RajaGrafindo Persada, dalam Penyelenggaraan pemerintah Negara, 2007).

Hartono, Sunaryadi, Penelitian Hukum di Indonesia Pada Akhir Abad ke-20, (Bandung: Alumni, 1994).

Ratna Nurul Afifah, Praperadilan dan Ruang Lingkupnya, (Jakarta: Akademika Presindo, 1986).

Marjuki, Peter Mahmud, Penelitian Hukum, Disertasi pada Fakultas Pasca Sarjana Universitas Indonesia, Jakarta, 1990, hlm, 308.

Catatan Kuliah Politik Hukum, Dosen Pengampu Retno Saraswati, SH, M. Hum

Materi Kuliah Politik Hukum Dosen Pengampu Barda Nawawi Arif.

(Jakarta: Prenada Media Group, 2005).

Ibrahim, Jonny, Teori dan Metodologi Penelitian Hukum Normatif, (Malang: Banyumedia Publsising, 2007).

Soekanto, Soerjono, Pengantar Penelitian Hukum, (Jakarta: UI-Press, 1986).

\section{B. Peraturan Perundang-Undang:}

Undang-Undang Dasar Negara Republik Indoneeia

Tahun 1945.

Undang-undang Nomor 8 Tahun 1981 tentang Kitab Undang-undang Hukum Acara Pidana (KUHAP). 